\title{
MODALITAS BAHASA INDONESIA DALAM TALK SHOW MATA NAJWA
}

\author{
Siti Nur Aisyah \\ Pendidikan Bahasa dan Sastra Indonesia \\ Universitas Muhammadiyah Jember \\ E-mail: snuraisy2997@gmail.com
}

DOI: http://dx.doi.org/10.32528/bb.v4i2.2561

Diterima: 18 Juli 2018

Diterbitkan: 30 Oktober 2019

\begin{abstract}
ABSTRAK
Penelitian ini bertujuan untuk mendeskripsikan bentuk-bentuk modalitas dan sikap yang diungkapkan penutur pada tuturan Talk Show Mata Najwa. Pembuktian dari pernyataan yang digunakan oleh penutur dilihat dari reaksi bahasa yang diucapkannya. Ragam modalitas yang digunakan dalam penelitian ini yaitu modalitas intensional, modalitas epistemik, modalitas deontik dan modalitas dinamik. Penelitian ini mengambil sumber data dari talk show Mata Najwa episode satu atau dua (debat tim sukses calon presiden nomor satu dan dua). Data penelitian ini berupa tuturan dan sikap penutur dari talk show Mata Najwa. Masalah dalam penelitian ini adalah bagaimana bentuk modalitas tuturan dan sikap yang diungkapkan oleh tim debat dan diskusi di talk show Mata Najwa. Metode penelitian ini adalah kualitatif deskriptif. Teknik pengumpulan data berupa teknik simak bebas libat cakap dan catat. Instrumen penelitian ini yaitu peneliti. Tabel analisis data dan transkrip data digunakan untuk membantu peneliti untuk menganalisis data. Tabel transkrip data digunakan untuk mengklasifikasikan ragam modalitas yang diungkapkan. Tabel analisis data digunakan untuk mendeskripsikan maksud tuturan dengan ragam modalitas bahasa Indonesia. Teknik pengecekan keabsahan data yang digunakan berupa ketekunan pengamatan. Teknik ketekunan pengamatan dilakukan untuk mengetahui data yang dihasilkan dapat dipercaya. Hasil dari penelitian ini menunjukkan bahwa penggunaan modalitas epistemik sering digunakan pada proses debat dan diskusi. Penggunaan modalitas epistemik banyak digunakan dengan alasan bahwa masalah diskusi mengandung kesalahan yang buruk dan cenderung tidak dapat diperbaiki. Penggunaan ungkapan modalitas epistemik berisi penegasan yang mengandung informasi. Informasi tersebut mengandung unsur kemungkinan tentang 'pengetahuan' dan 'keyakinan' antara penutur dan lawan tutur. Penggunaan unsur kemungkinan tentang 'pengetahuan' memiliki tujuan bahwa penutur tidak lebih baik pengetahuannya dari pada lawan tutur. Penggunaan unsur kemungkinan tentang 'keyakinan' berperan sebagai pendukung dari unsur kemungkinan tentang 'pengetahuan'. Ungkapan penegasan sering dinyatakan dengan kata 'harus' yang berfungsi sebagai sarana orasi. Tujuan orasi tersebut untuk menunjukkan keunggulan dan kesalahan dari lawan diskusi.
\end{abstract}

Kata Kunci: modalitas, modalitas epistemik, Mata Najwa

\section{ABSTRACT}

This study aims to describe the forms of modalities and attitudes expressed by speakers at the speech of Mata Najwa Talk Show. Evidence of the statement stated by speakers is seen from the reaction of the language spoken. The varieties of modalities used in this study are intentional modalities, epistemic modalities, deontic modalities and dynamic modalities. The data of this study was taken from Mata Najwa talk show episode one or two (debating the success teams of presidential candidates number one and two). This research data are in the form of speeches and attitudes of speakers from Mata Najwa talk 
show. The problem in this research is how the form of speech modalities and attitudes expressed by the debate team and discussion in Mata Najwa talk show. This research employed descriptive qualitative method. The data collection technique is in the form of skillful and note-taking listening techniques. The instrument of this research is researchers. Data analysis tables and data transcripts are used to help researchers analyze data. Data transcript tables werere used to classify the various modalities disclosed. The data analysis table was used to describe the speech intention with varieties of Indonesian language modalities. The technique of checking the validity of the data used is in the form of deep observation. This observation technique is done to assure that the data generatd is reliable. The results of this study indicated that epistemic modalities is often used in the debate and discussion process. The epistemic modalities is widely used since the discussion often contains serious errors and tend to be irreparable. The use of expressions of epistemic modality contains affirmations that contain information. This information contains possible elements of 'knowledge' and 'beliefs' between speakers and opponents. The use of the possible element of 'knowledge' has the purpose that the speaker is not having better knowledge than the opponent. The use of a possible element of 'beliefs' serves as a supporter of the element of possibility about 'knowledge'. Affirmation expressions are often expressed by the word 'must' which functions as a means of speech. The purpose of the oration is to show the superiority and mistakes of the opponents in the discussion..

Keywords: modality, epistemic modality, Mata Najwa

\section{PENDAHULUAN}

Setiap tuturan yang diungkapkan oleh manusia tidak lepas dari keyakinan dan sikap dari manusia itu sendiri. Sikap dan keyakinan ketika mengungkapkan tuturan tersebut biasa dikenal sebagai modalitas bahasa. Menurut Wijana (2015, hal. 117) menyatakan bahwa modalitas adalah sikap dan keyakinan yang terkandung dalam tuturan pembicara. Cara untuk mengungkapkan tuturan dari pembicara tersebut bisa dengan berbagai cara, yaitu bisa dengan memakai kata nomina, adverbia ataupun kata bantu modalitas. Pendapat tersebut senada dengan Chaer (2012, hal. 262) yang menyatakan bahwa modalitas merupakan kata keterangan di dalam kalimat yang mengandung unsur sikap penutur terhadap sesuatu hal yang dibicarakannya. Adapun menurut Santoso (2008, hal. 232) ungkapan modalitas sering digunakan dalam ranah polotik karena mengandung nilai ekspresif yang berfungsi sebagai pernyataan autoritas penutur terhadap kebenaran atau kemungkinan representatif realitas. Dari pernyataan tersebut maka modalitas dalam bahasa Indonesia merupakan sebuah reaksi bahasa yang diungkapkan oleh penutur dalam berbagai hal yang dibicarakan. Reaksi tersebut berisi tentang rasa percaya dan perilaku dari penutur itu sendiri dari berbagai hal yang dibicarakannya. Menurut Afyolanda, dkk (2018, hal. 153) menyatakan bahwa fungsi estetis juga bisa diungkapkan dengan modalitas yang biasanya dinyatakan dengan fungsi mengubah nada, menyatakan sikap dan menyatakan suasana hati. Menurut Prihantoro \& Fitriani (2015, hal. 8) penggunaan modalitas bahasa
Indonesia untuk mengungkapkan sikap penutur yang bisa berbentuk kalimat positif dan kalimat negatif. Pendapat tersebut senada dengan Damayanti (2012, hal. 12) yang menyatakan bahwa kata bantu modalitas bahasa Indonesia berupa adverbia ekstraklausal dan intraklausal. Tetapi ada pengecualian dalam penggunaan kata bantu modalitas epistemik dan modalitas dinamik yang hanya menggunakan adverbia intraklausal saja. Adapun menurut Saputri (hal. 317-318) menyatakan bahwa bentuk dan kategori adverbia penanda modalitas bisa digunakan pada materi ajar Kompetensi Inti yang berupa faktual, konseptual, serta prosedural yang terbentuk menjadi frasa untuk mengisi fungsi kalimat tunggal dan kalimat majemuk.

Menurut Wijana (2015, hal. 118-117) terdapat lima ragam modalitas dalam bahasa Indonesia yaitu meliputi modalitas deontik, modalitas epistemik, modalitas potensial, modalitas keraguan dan modalitas kepastian. Modalitas deontik merupakan modalitas yang menyatakan tentang sesuatu hal yang bersifat harus dan formal, seperti kata 'harus' dan 'mesti'. Adapun modalitas epistemik adalah modalitas yang menyatakan tentang sesuatu yang bersifat wajib dan tingkat keharusannya lebih kuat dari pada modalitas deontik. Selanjutnya modalitas epistemik biasanya dinyatakan dengan kata 'wajib' dan 'mesti'. Selanjutnya modalitas potensial adalah modalitas yang digunakan untuk menyatakan sesuatu hal yang memiliki kekuasaan bagi penuturnya. Contoh dari penggunaan modalitas potensial baiasanya ditandai oleh kata 'dapat', 'bisa', 'boleh', ataupun 
'tidak boleh. Adapun modalitas keraguan merupakan modalitas yang digunakan untuk menyatakan sesuatu hal yang bersifat tidak atau belum tentu terjadi. Penggunaan modalitas keraguan ditandai oleh penggunaan kata 'mungkin' dan 'barangkali'. Sedangkan modalitas kepastian merupakan modalitas yang digunakan untuk menyatakan sesuatu hal yang bersifat pasti dan sudah tetap. Modalitas kepastian biasanya ditandai oleh kata 'pasti', 'tentu', dan 'niscaya'.

Adapun menurut Alwi (1992, hal. 36-261) mengungkapkan bahwa ragam modalitas meliputi modalitas internasional, modalitas epistemik, modalitas deontik, dan modalitas dinamik. Modalitas intensional merupakan modalitas yang digunakan untuk mengungkapkan keinginan, harapan, ajakan, pembiaran, dan permintaan. Adapun modalitas epistemik merupakan modalitas yang digunakan untuk mengungkapkan kemungkinan, keteramalan, keharusan dan kepastian. Sedangkan modalitas deontik merupakan modalitas yang digunakan untuk mengungkapkan suatu ungkapan izin dan perintah. Adapun modalitas dinamik merupakan modalitas yang digunakan untuk mengungkapkan suatu kemampuan.

Senada dengan pendapat di atas, Chaer (2012, hal. 262-263) menyatakan bahwa empat ragam modalitas bahasa Indonesia yaitu modalitas intensional, modalitas epistemik, modalitas deontik, dan modalitas dinamik. Modalitas intensional adalah modalitas yang digunakan untuk mengungkapkan sesuatu hal yang berisi tentang kehendak, harapan, anjuran, ataupun permintaan. Adapun modalitas epistemik merupakan modalitas yang digunakan untuk menyatakan sesuatu hal yang bersifat kemungkinan, kepastian, dan keharusan. Sedangkan modalitas deontik yaitu modalitas yang diungkapkan terhadap sesuatu hal yang mengandung unsur kerelaan dan persetujuan. Selanjutnya modalitas dinamik merupakan modalitas yang dipakai untuk mengungkapkan sesuatu hal yang mengandung kesanggupan ataupun kecakapan seseorang. Adapun menurut Faradi (2015, hal. 16) menyatakan bahwa penggunaan modalitas epistemik berupa ungkapan keharusan lebih banyak digunakan dalam proses debat yang berfungsi untuk meyakinkan mitra tutur.

Reaksi bahasa yang mencerminkan perilaku penutur dapat dijumpai dari berbagai bentuk komunikasi, baik komunikasi formal ataupun non formal. Terlebih lagi pada saat penutur tersebut berada dalam pembicaraan yang berisi benar dan salah dalam sebuah pendapat. Salah satunya dalam komunikasi pada situasi debat dan diskusi. Dalam diskusi, reaksi bahasa tersebut terdapat pada usaha penutur dalam bertukar ide terhadap sesuatu yang dianggap benar dan salah. Sedangkan dalam situasi debat, reaksi bahasa tersebut terdapat pada alasan penutur dalam mempertahankan ide yang disampaikan, terlebih dalam usaha pembantahan terhadap alasan dari penutur lainnya. Tidak sedikit dari penutur yang memaksakan pendapatnya untuk disetujui oleh penutur lain. Karena merasa bahwa pendapat penutur tersebutlah yang benar, terlepas pada topik apa yang dibicarakannya.

Penggunaan modalitas dalam reaksi tertentu sering kali muncul untuk mempertahankan pendapat penutur. Bahkan tidak sedikit dari penutur yang menggunakan kata bantu modalitas tersebut untuk memaksakan pendapatnya serta tidak ingin disalahkan oleh lawan tuturnya. Contoh penggunaan modalitas adalah "Tetapi kita juga harus mengerti bahwa pengakuan yang diberikan Ratna ini sepanjang dia belum mengaku dia berbohong itu belum termasuk kategori hoax". Kalimat tersebut terdapat kata harus yang mengandung unsur keharusan yang termasuk pada modalitas epistemik. Ungkapan tersebutlah yang mendukung penelitian ini, sehingga memiliki fokus untuk mendeskripsikan penggunaan modalitas bahasa Indonesia pada acara Mata Najwa episode 10 Oktober 2018 yang berjudul "Satu atau Dua". Alasan peneliti memilih acara Mata Najwa karena dalam acara tersebut memperdebatkan permasalahan yang masih baru yaitu pandangan calon presiden dan wakil presiden tahun 2019-2023 terhadap masalah-masalah yang dihadapi oleh masyarakat pada saat ini. Proses diskusi dan debat yang terdapat dalam acara Mata Najwa tersebut menghadirkan dua pihak pembicara yang masingmasing memiliki pendapat dari berbagai pandangan pemikiran yaitu pihak Jokowi-Ma'ruf dan pihak Prabowo-Sandi. Sehingga dalam diskusi dan debat tersebut tidak hanya berlangsung dalam dua arah, melainkan dari berbagai arah. Bergantung pada pemimpin proses diskusi dan debat yang memberikan kesempatan pada para pembicara untuk mengungkapkan pemikirannya. Penelitian ini menggunakan kajian Sintaksis tentang modalitas Bahasa Indonesia.

Penelitian ini relevan dengan penelitian "Analisis Modalitas Tuturan Basuki Cahaya Purnama dalam Wacana Kalijodo" yang ditulis oleh Yusep Ahmadi F. Masalah dalam penelitian tersebut adalah bentuk modalitas tuturan, sikap, dan representasi Gubernur Jakarta, Basuki Cahaya Purnama, dalam wacana Kalijodo. Hasil penelitian tersebut adalah temuan modalitas deontik-perintah yang dominan ditambah dengan modalitas epistemik kepastian diurutan kedua. Hasil tersebut menunjukkan bahwa Cahaya Purnama dalam menanggulangi kasus Kalijodo dengan pendekatan 
perintah yang tegas tanpa keraguan. Perbedaan penelitian ini dengan penelitian tersebut. Penelitian ini mendeskripsikan tentang penggunaan modalitas bahasa Indonesia dengan menitikberatkan pada bentuk-bentuk modalitas dan sikap yang diungkapkan penutur pada tuturan peserta debat pada acara Mata Najwa. Sedangkan pada penelitian Yusep Ahmadi F. menitikberatkan pada modalitas epistemik kepastian saja dan makna dari tuturan Cahaya Purnama.

\section{METODE PENELITIAN}

Penelitian ini menggunakan metode berupa kualitatif deskriptif. Kualitatif deskriptif digunakan untuk proses pendeskripsian yang berfungsi sebagai sarana untuk mengetahui semua tujuan penelitian yang telah ditentukan serta mempermudah dalam pengelompokkan data sesuai kategori yang telah ditentukan untuk kemudian dilakukan analisis data selanjutnya. Adapun tahap sebelum analisis data yaitu berupa tahap pengumpulan data. Penelitian ini dalam tahap pengumpulan data menggunakan teknik simak bebas libat cakap dan catat. Teknik simak bebas libat cakap dilakukan oleh peneliti untuk mengetahui modalitas apa saja yang terdapat pada sumber data. Teknik simak bebas libat cakap digunakan dengan cara peneliti mencari data dengan melihat video talk show Mata Najwa tanpa terlibat secara langsung dalam diskusi dan debat pada acara tersebut. Adapun teknik simak dilakukan dengan cara menyatat data-data yang ditemukan dalam tahap teknik simak bebas libat cakap.

Adapun tahap selanjutnya yaitu tahap analisis data. Tahap analisis data pada penelitian ini berupa tabel transkrip data dan tabel analisis data. Tabel transkrip data digunakan untuk mencatat, menguraikan secara terperinci dan menyederhanakan data yang diperoleh dari teknik catat. Adapun teknik analisis data digunakan untuk menganalisis dan mendeskripsikan data secara rinci berdasarkan klasifikasi yang telah ditentukan. Setelah tahap analisis data, tahap selanjutnya yaitu teknik pengecekan keabsahan data. Teknik pengecekan keabsahan data dalam penelitian ini berupa teknik ketekunan pengamatan. Teknik ketekunan pengamatan dilakukan dengan cara peneliti melakukan pembacaan berulang-ulang dan mengamati data yang telah dianalisis untuk memperoleh data yang hasilnya tetap dan reliabel.

\section{PEMBAHASAN}

1.Bentuk-bentuk Penggunaan Modalitas Bahasa Indonesia Dalam Talk Show Mata Najwa.

\section{a) Modalitas Intensional}

Modalitas intensional merupakan ungkapan sesuatu hal yang berisi kehendak, harapan, anjuran, ataupun permintaan.

\section{(1) Mari kita hidup dengan jujur (M.In 1)}

Data M.In 1 tersebut menunjukkan bahwa modalitas yang digunakan adalah modalitas intensional. Data M.In 1 tersebut mengandung unsur anjuran. Data M.In 1 ditandai oleh kata 'mari' yang menekankan bahwa 'ajakan untuk hidup dengan jujur tanpa adanya keberpura-puraan dan unsur kebohongan'. Pada data M.In 1 tersebut penutur menggunakan kata kita untuk menyampaikan sebuah ajakan agar dapat melaksanakannya secara bersama-sama. Penutur dalam tuturannya tidak hanya mengajak mitra tutur saja, melainkan juga orang lain yang mendengarkan tuturan tersebut. Apabila kata 'mari' tidak ada dalam tuturan, maka tuturan tersebut tidak tergolong pada modalitas intensional. Alasan tersebut dapat dilihat dari makna tuturan setelah kata 'mari' tidak ada, maka makna tuturan tersebut bukanlah mengandung unsur ajakan. Melainkan memiliki maksud untuk memberikan sebuah pernyataan yang mengandung unsur berita tentang suatu informasi bahwa 'kita hidup dengan jujur'. Sehingga apabila tuturan tersebut terdapat kata 'mari', maka tuturan tersebut memiliki manfaat bagi penuturnya untuk mengajak mitra tutur tanpa adanya unsur paksaan. Ajakan seperti itulah yang menjadikan tuturan tersebut semakin mendukung orasi yang dilakukan oleh penutur.

Data M.In 1 mengandung penggunaan modalitas intensional dikarenakan terdapatnya kata 'mari' dalam tuturan tersebut. Data M.In 1 tersebut sesuai dengan salah satu sifat modalitas intensional menurut Chaer (2012, hal. 263) yang menyatakan bahwa modalitas intesional merupakan modalitas yang digunakan untuk mengungkapkan sesuatu hal yang berisi tentang anjuran. Atas landasan teori tersebutlah, data tuturan di atas digolongkan pada data tuturan modalitas intensional.

Berdasarkan analisis data M.In 1 di atas, data M.In 1 dapat dikategorikan menjadi modalitas intensional. Oleh karena itu, dapat disimpulkan bahwa: (1) data M.In 1 dikategorikan sebagai modalitas intensional karena terdapat kata 'mari'; (2) data M.In 1 tidak bisa dikategorikan sebagai modalitas intensional, apabila pada data M.In 1 tidak terdapat kata 'mari' sehingga akan berubah fungsi menajdi kalimat berita; dan (3) data M.In 1 mengandung unsur ajakan. 
b) Modalitas Epistemik

Modalitas epistemik merupakan ungkapan yang berisi unsur kemungkinan, keteramalan, keharusan dan kepastian.

(2) Tetapi kita juga harus mengerti bahwa pengakuan yang diberikan Ratna ini sepanjang dia belum mengaku dia berbohong itu belum termasuk kategori hoax (M.Ep 5)

Data M.Ep 5 tersebut menunjukkan bahwa modalitas yang digunakan adalah modalitas Epistemik. Data M.Ep 5 mengandung unsur keharusan. Data M.Ep 5 ditandai oleh kata 'harus' yang menekankan bahwa 'pengakuan Ratna belum dikategorikan hoax sebelum dia mengaku bahwa dia berbohong'. Penutur menggunakan kata 'harus' agar menekankan kepada mitra tutur bahwa ada 'ukuran tersendiri berita tersebut dikatakan hoax atau tidak'. Penggunaan kata 'harus' tersebut juga mengindikasikan bahwa mitra tutur wajib dan dapat membedakan 'berita tersebut sudah tergolong berita hoax atau tidak'. Apabila kata 'harus' tidak ada dalam tuturan, maka tuturan tersebut tidak tergolong pada modalitas epistemik. Alasan tersebut dapat dilihat dari makna tuturan setelah kata tidak adanya 'harus', maka makna tuturan tersebut bukanlah mengandung unsur keharusan. Melainkan memiliki maksud untuk memberikan sebuah pernyataan tentang mitra tutur yang sudah mengerti 'ukuran berita yang dimaksud' tergolong bukan berita hoax. Sehingga apabila tuturan tersebut terdapat kata 'harus', maka tuturan tersebut memiliki manfaat bagi penutur agar dapat menyampaikan perintahnya kepada mitra tutur bahwa mitra tutur harus bisa membedakan antara 'berita hoax atau tidak'. Sehingga antara penutur dan mitra tutur tidak ada yang salah menafsirkan tentang 'hoax atau tidaknya sebuah berita'. Selain itu, perintah tersebut semakin mendukung penutur dalam melakukan orasinya untuk memberikan sebuah pengertian bagi mitra tutur tentang berita hoax yang ada di Indonesia, yang cenderung masih menjadi masalah yang perlu penanganan secara tepat.

Data M.Ep 5 mengandung penggunaan modalitas epistemik dikarenakan terdapatnya kata 'harus' dalam tuturan tersebut. Data M.Ep 5 tersebut sesuai dengan salah satu sifat modalitas epistemik menurut Chaer (2012, hal. 263) yang menyatakan bahwa modalitas epistemik merupakan modalitas yang digunakan untuk menyatakan sesuatu hal yang bersifat keharusan. Atas landasan teori tersebutlah, data M.Ep 5 digolongkan pada data tuturan modalitas epistemik.
Berdasarkan analisis data M.Ep 5 di atas, data M.Ep 5 dapat dikategorikan menjadi modalitas epistemik. Oleh karena itu, dapat disimpulkan bahwa: (1) data M.Ep 5 dikategorikan sebagai modalitas epistemik karena terdapat kata 'harus'; (2) data M.Ep 5 tidak bisa dikategorikan sebagai modalitas epistemik, apabila pada data M.Ep 5 tidak terdapat kata 'harus' sehingga akan berubah fungsi menjadi kalimat berita; dan (3) data M.Ep 5 mengandung unsur keharusan.

\section{c) Modalitas Deontik}

Modalitas deontik merupakan ungkapan yang berisi unsur izin dan perintah.

(3) Saya akan kembali ke poin itu, tapi anda tanggapi dulu yang empati (M.De 3)

Data M.De 3 tersebut menunjukkan bahwa modalitas yang digunakan adalah modalitas deontik yang mengandung unsur perintah. Data M.De 3 tersebut ditandai oleh kalimat imperatif 'anda tanggapi dulu yang empati' yang menekankan perintah bagi mitra tutur agar menanggapi terlebih dahulu tentang 'empati'. Penekanan tersebut juga menimbulkan unsur persetujuan antara penutur dan mitra tutur. Unsur persetujuan juga didukung oleh kalimat sbelumnya yaitu 'saya akan kembali ke poin itu' dimana poin yang dimaksud adalah poin yang lain, tetapi poin yang lain tersebut belum bisa dibahas karena yang dibahas pada saat itu adalah tentang empati. Apabila kalimat 'anda tanggapi dulu yang empati' tidak ada dalam tuturan, maka tuturan tersebut tidak tergolong pada modalitas deontik. Alasan tersebut dapat dilihat dari makna data M.De 3 setelah kalimat 'anda tanggapi dulu yang empati' tidak ada, maka makna tuturan tersebut bukanlah mengandung unsur perintah. Melainkan memiliki maksud untuk memberikan sebuah pernyataan yang mengandung unsur berita tentang suatu informasi bahwa pemandu diskusi 'akan kembali ke poin tersebut'. Namun tidak ada kejelasan tentang kapan pemandu diskusi tersebut akan kembali membahas poin tersebut. Sehingga apabila data M.De 3 tersebut terdapat kalimat 'anda tanggapi dulu yang empati', maka data M.De 3 tersebut memiliki manfaat bagi penuturnya untuk memerintah dengan memberikan komando kepada mitra tuturnya agar memberikan tanggapan terlebih dahulu tentang persoalan 'empati'. Sekalipun perintah tersebut tidak diucapkan dengan kalimat deklaratif, tetapi tetap saja ungkapan tersebut mengandung unsur perintah, meskipun diungkapkan dengan kalimat imperatif.

Data M.De 3 di atas mengandung penggunaan modalitas deontik dikarenakan terdapatnya kalimat 'kita bahas satu-satu' dalam 
tuturan tersebut. Data M.De 3 tersebut sesuai dengan pendapat Chaer (2012, hal. 263) yang menyatakan bahwa modalitas deontik merupakan modalitas yang diungkapkan terhadap sesuatu hal yang mengandung unsur kerelaan dan persetujuan. Atas landasan teori tersebutlah, data tuturan di atas digolongkan pada data tuturan modalitas deontik.

Berdasarkan analisis data M.De 3 di atas, data M.De dapat dikategorikan menjadi modalitas deontik. Oleh karena itu, dapat disimpulkan bahwa: (1) data M.De 3 dikategorikan sebagai modalitas deontik karena terdapat kalimat 'anda tanggapi dulu yang empati'; (2) data M.De 3 tidak bisa dikategorikan sebagai modalitas deontik, apabila pada data M.De 3 tidak terdapat kalimat 'anda tanggapi dulu yang empati' sehingga akan berubah fungsi menjadi kalimat berita; dan (3) data M.De 3 mengandung unsur perintah.

\section{d) Modalitas Dinamik}

Modalitas dinamik merupakan ungkapan untuk menyatakan tentang kemampuan seseorang.

(4) Seorang Presiden bisa salah mengangkat dan itu berbahaya sekali (M.Di 1)

Data M.Di 1 tersebut menunjukkan bahwa modalitas yang digunakan adalah modalitas dinamik yang mengandung unsur menyatakan kemampuan seseorang. Data M.Di 1 tersebut ditandai oleh kata 'bisa' yang menekankan bahwa 'Presiden bisa salah mengangkat menteri, itu adalah hal yang berbahaya'. Kata 'bisa' tersebut mengindikasikan bahwa 'Presiden' sudah biasa melakukan pekerjaan yang dimaksud. Namun, ada kesalahan dalam salah satu pekerjaan tersebut. Sehingga ada permasalahan dari mitra tutur yang secara tidak langsung menuntut keprofesionalan dari 'Presiden' tersebut. Karena mitra tutur sudah beranggapan bahwa 'pekerjaan sebagai Presiden' sudah harus dan sanggup melakukan pekerjaanpekerjaannya sebagai Presiden dengan benar. Apabila kata 'bisa' tidak ada dalam tuturan, maka tuturan tersebut tidak tergolong pada modalitas dinamik. Alasan tersebut dapat dilihat dari makna tuturan setelah kata 'bisa' tidak ada, maka makna tuturan tersebut bukanlah mengandung unsur menyatakan kemampuan seseorang. Melainkan memiliki maksud untuk memberikan sebuah pernyataan yang mengandung unsur berita tentang suatu informasi bahwa 'akan berbahaya sekali, jika presiden salah mengangkat menteri'. Sehingga apabila data M.Di 1 tersebut terdapat kata 'bisa', maka tuturan tersebut memiliki manfaat bagi penuturnya untuk mengungkapkan kemampuan dari Presiden tersebut. Selain itu, kata 'bisa' tersebut sudah melekat dengan sifat yang sedang di bahas. Penggunaan kata 'bisa' tersebutlah yang menjadikan tuturan tersebut dikategorikan pada modalitas dinamik.

Data M.Di 1 di atas mengandung penggunaan modalitas dinamik dikarenakan terdapatnya kata 'bisa' dalam tuturan tersebut. Data M.Di 1 tersebut sesuai dengan pendapat Chaer (2012, hal. 263) yang menyatakan bahwa modalitas dinamik merupakan modalitas yang dipakai untuk mengungkapkan sesuatu hal yang mengandung kesanggupan ataupun kecakapan seseorang. Atas landasan teori tersebutlah, data tuturan di atas digolongkan pada data tuturan modalitas dinamik.

Berdasarkan analisis data M.Di 1 di atas, data M.Di 1 dapat dikategorikan menjadi modalitas dinamik. Oleh karena itu, dapat disimpulkan bahwa: (1) data M.Di 1 dikategorikan sebagai modalitas dinamik karena terdapat kata 'bisa'; (2) data M.Di 1 tidak bisa dikategorikan sebagai modalitas dinamik, apabila pada data M.Di 1 tidak terdapat kata'bisa' sehingga akan berubah fungsi menjadi kalimat berita; dan (3) data M.Di 1 mengandung unsur menyatakan kemampuan seseorang.

\section{Maksud Sikap Penutur Dalam Tuturan Talk Show Mata Najwa a) Modalitas Intensional}

Modalitas intensional merupakan ungkapan sesuatu hal yang berisi kehendak, harapan, anjuran, ataupun permintaan.

(1) Pak Prabowo selalu konsisten untuk memperhatikan kesejahteraan karyawannya, itu penting. Jadi jangan sampai, tradisi fitnah seperti itu, itu kemudian dihidupkan (M.In 7)

Data M.In 7 di atas memiliki maksud untuk menyampaikan harapan penutur kepada mitra tutur agar 'tidak melakukan kebiasaan fitnah'. Data M.In 7 tersebut disampaikan oleh penutur dengan menjelaskan terlebih dahulu permasalahan yang dibahas secara menyeluruh. Kemudian penutur menyampaikan harapannya untuk mitra tutur agar tidak salah pemahaman lagi. Apabila frasa 'jangan sampai' tidak ada dalam tuturan, maka tuturan tersebut tidak tergolong pada modalitas intensional. Alasan tersebut dapat dilihat dari makna tuturan setelah frasa 'jangan sampai' tidak ada, maka makna tuturan tersebut bukanlah mengandung unsur harapan. Melainkan memiliki maksud untuk memberikan perintah 'untuk menghidupkan kebiasaan fitnah'. Sehingga apabila tuturan tersebut terdapat kata 'jangan sampai', maka tuturan tersebut memiliki manfaat bagi 
penuturnya untuk mengungkapkan harapannya setelah memberikan penjelasan secara utuh. Selain itu, frasa 'jangan sampai' tersebut bisa digunakan untuk menyampaikan ungkapan harapan. Meskipun dalam modalitas intensional tidak terdapat frasa 'jangan sampai', tetapi frasa tersebut memiliki makna yang sama dengan 'hendaknya jangan'. Penggunaan frasa tersebutlah yang menjadikan tuturan tersebut masih bisa dikategorikan pada modalitas intensional.

Data M.In 7 di atas mengandung penggunaan modalitas intensional dikarenakan terdapatnya kata 'jangan sampai' yang mengindikasikan agar mitra tutur 'tidak melakukan' hal tersebut. Data M.In 7 tersebut merupakan ungkapan harapan yang berupa permintaan dari penutur, agar mitra tutur tidak melakukan 'hal tersebut lagi'. Frasa 'jangan sampai' memiliki maksud yang sama dengan frasa 'hendaknya jangan' pada penggunan modalitas intensional harapan. Data M.In 7 tersebut sesuai dengan pendapat Alwi (1992, hal. 36-261) yang menyatakan bahwa modalitas intensional harapan ditandai oleh kata harap, harapkan, mengharapkan, mengharap, hendaknya, berdoa, doakan, mendoakan, mudahmudahan, moga-moga, dan semoga. Atas landasan teori tersebutlah, data M.In 7 di atas digolongkan pada data tuturan modalitas intensional harapan yang memiliki maksud permintaan.

Berdasarkan analisis data M.In 7 di atas, data M.In 7 dapat dikategorikan menjadi modalitas intensional. Oleh karena itu, dapat disimpulkan bahwa: (1) data M.In 7 dikategorikan sebagai modalitas intensional karena terdapat frasa 'hendaknya jangan'; (2) data M.In 7 tidak bisa dikategorikan sebagai modalitas intensional, apabila pada data M.In 7 tidak terdapat frasa 'hendaknya jangan' sehingga akan berubah fungsi menjadi ungkapan perintah; dan (3) data M.In 7 mengandung unsur harapan.

\section{b) Modalitas Epistemik}

Modalitas epistemik merupakan ungkapan yang berisi unsur kemungkinan, keteramalan, keharusan dan kepastian.

(2) Oleh sebab itu, Indonesia harus hadir sebagai negara yang adil dan makmur, dan mereka ini adalah tokoh yang tepat memimpin Indonesia. Karena Pak Prabowo memiliki kepemimpinan yang tidak mudah dikontrol oleh siapapun dan beliau akan menghadirkan adil dan makmur untuk seluruh rakyat Indonesia (M.Ep 7)
Data M.Ep 7 di atas memiliki maksud untuk menyampaikan ungkapan keharusan penutur kepada mitra tutur agar 'memilih Pak Prabowo sebagai pemimpin Indonesia'. Data M.Ep 7 tersebut disampaikan oleh penutur dengan menyatakan kelebihan 'Pak Prabowo' dengan menghubungkan keadaan Indonesia di masa mendatang. Kemudian penutur menyampaikan ungkapan keharusan agar mitra tutur memilih 'Pak Prabowo" untuk menjadi 'Presiden'. Apabila kata 'harus' tidak ada dalam data M.Ep 7, maka tuturan tersebut tidak tergolong pada modalitas epistemik. Alasan tersebut dapat dilihat dari makna tuturan setelah kata 'harus' tidak ada, maka makna tuturan tersebut bukanlah mengandung unsur keharusan yang berupa ajakan. Melainkan memiliki maksud untuk memberikan sebuah pernyataan yang mengandung unsur berita tentang suatu informasi bahwa 'Indonesia sudah hadir sebagai negara yang adil dan makmur'. Sehingga apabila tuturan tersebut terdapat kata 'harus', maka tuturan tersebut memiliki manfaat bagi penuturnya untuk mengungkapkan kelebihan seseorang melalui orasi yang dilakukan penutur. Selain itu, kata 'harus' tersebut diungkapkan setelah memberikan penjelasan tentang keadaan 'Indonesia'. Sehingga penggunaan kata 'harus' tersebut dijadikan sebuah ajakan yang cenderung memerintah, guna untuk menjadikan tuturan tersebut dapat meyakinkan mitra tutur.

Data M.Ep 7 di atas mengandung penggunaan modalitas epistemik dikarenakan terdapatnya kata 'harus' yang mengindikasikan agar mitra tutur 'melakukan' hal yang dimaksudkan oleh penutur. Data M.Ep 7 tersebut merupakan ungkapan keharusan yang berupa ajakan dari penutur, agar mitra tutur memilih 'Pak Prabowo sebagai Presiden Indonesia'. Kata 'harus' memiliki maksud untuk melakukan sesuatu hal yang diungkapkan pada penggunan modalitas epistemik keharusan. Data M.Ep 7 tersebut sesuai dengan pendapat Alwi (1992, hal. 260) yang menyatakan bahwa modalitas epistemik keharusan ditandai oleh kata harus, mesti, wajib, perlu, patut, seharusnya, semestinya, sebaiknya, sepantasnya, seyogianya, selayaknya, sepatutnya, patut-patutnya, dan pantas-pantsanya. Atas landasan teori tersebutlah, data tuturan di atas digolongkan pada data tuturan modalitas epistemik kaharusan yang memiliki maksud mengajak.

Berdasarkan analisis data M.Ep 7 di atas, data M.Ep 7 dapat dikategorikan menjadi modalitas epistemik. Oleh karena itu, dapat disimpulkan bahwa: (1) data M.Ep 7 dikategorikan sebagai modalitas epistemik karena terdapat kata 'harus'; (2) data M.Ep 7 tidak bisa dikategorikan sebagai modalitas epistemik, apabila pada data M.Ep 7 tidak terdapat kata 'harus' sehingga akan berubah 
fungsi menjadi ungkapan berita; dan (3) data M.Ep 7 mengandung unsur keharusan yang berupa ajakan.

\section{c) Modalitas Deontik}

Modalitas deontik merupakan ungkapan yang berisi unsur izin dan perintah.

(3) Silakan ditanggapi (M.De 9)

Data M.De 9 di atas memiliki maksud untuk menyampaikan perintah penutur kepada mitra tutur agar 'menanggapi masalah yang sedang dibahas'. Data M.De 9 tersebut disampaikan oleh penutur dengan mempersilakan secara langsung kepada mitra tutur. Kemudian mitra tutur memberikan reaksi dengan memberi tanggapan terhadap masalah tersebut. Apabila kata 'silakan' tidak ada dalam data M.De 9, maka tuturan tersebut tidak tergolong pada modalitas deontik. Alasan tersebut dapat dilihat dari makna tuturan setelah kata 'silakan' tidak ada, maka makna tuturan tersebut bukanlah mengandung unsur perintah yang berupa permintaan. Melainkan tidak memiliki kejelasan maksud, karena dalam tuturan 'ditanggapi' tersebut tidak jelas siapa dan apa yang ditanggapi. Sehingga apabila tuturan pada data M.De 9 terdapat kata 'silakan', maka tuturan tersebut memiliki manfaat bagi penuturnya untuk mengungkapkan perintahnya dengan cara mempersilahkan kepada mitra tutur. Penggunaan kata 'silakan' tersebutlah yang menjadikan tuturan tersebut dikategorikan pada modalitas deontik.

Data M.De 9 di atas mengandung penggunaan modalitas deontik dikarenakan terdapatnya kata 'silakan' yang mengindikasikan bahwa penutur 'mempersilakan atau memberi kesempatan' kepada mitra tutur. Tuturan tersebut merupakan ungkapan perintah yang berupa permintaan dari penutur, agar mitra tutur 'memberikan tanggapannya'. Kata 'silakan' secara tidak langsung memiliki maksud yang sama dengan kata 'memerintah' pada penggunan modalitas deontik perintah. Data M.De 9 tersebut sesuai dengan pendapat Alwi (1992, hal. 261) yang menyatakan bahwa modalitas deontik perintah ditandai oleh kata wajib, mesti, harus, haruskah, mengharuskan, diharuskan, perintahkan, memerintah, diperintahkan, larang, melarang, dilarang, tidak boleh, jangan. Atas landasan teori tersebutlah, data M.De 9 di atas digolongkan pada data tuturan modalitas deontik perintah yang memiliki maksud permintaan.

Berdasarkan analisis data M.De 9 di atas, data M.De 9 dapat dikategorikan menjadi modalitas deontik. Oleh karena itu, dapat disimpulkan bahwa: (1) data M.De 9 dikategorikan sebagai modalitas deontik karena terdapat kata 'silakan'; (2) data
M.De 9 tidak bisa dikategorikan sebagai modalitas deontik, apabila pada data M.De 9 tidak terdapat kata 'silakan' sehingga akan ada ketidakjelasan maksud pada data M.De 9 tersebut; dan (3) data M.De 9 mengandung unsur perintah yang berupa permintaan.

\section{d) Modalitas Dinamik}

Modalitas dinamik merupakan ungkapan untuk menyatakan tentang kemampuan seseorang.

(4) Tapi dalam alam demokrasi itu agak susah, tapi Pak Jokowi sanggup untuk melakukannya (M.Di 2)

Data M.Di 2 di atas memiliki maksud untuk menjelaskan kemampuan dari seseorang yang merupakan objek tuturan. Data M.Di 2 tersebut disampaikan oleh penutur dengan menjelaskan terlebih dahulu permasalahan yang dibahas secara menyeluruh. Kemudian penutur menyampaikan kesanggupan objek tuturan dalam menyelesaikan permasalahan tersebut, dengan tujuan agar mitra tutur memahami kelebihan dari seseorang tersebut. Apabila kata 'sanggup' tidak ada dalam data M.Di 2, maka tuturan tersebut tidak tergolong pada modalitas dinamik. Alasan tersebut dapat dilihat dari makna tuturan setelah kata 'sanggup' tidak ada, maka makna tuturan tersebut bukanlah mengandung unsur menyatakan kemampuan seseorang. Melainkan tidak memiliki kejelasan maksud dari tuturan tersebut, karena tuturan tersebut tidak ada kontunuitas dengan kalimat sebelumnya. Sehingga apabila tuturan data M.Di 2 terdapat kata 'sanggup', maka tuturan tersebut memiliki manfaat bagi penuturnya untuk mengungkapkan kesanggupan dari Pak Jokowi.

Data M.Di 2 di atas mengandung penggunaan modalitas dinamik dikarenakan terdapatnya kata 'sanggup' yang mengindikasikan tentang kemampuan dari 'Pak Jokowi' dalam penyelesaian masalah tersebut. Data M.Di 2 tersebut merupakan ungkapan kemampuan yang berupa meyakinkan mitra tutur terhadap kesanggupan dari 'Pak Jokowi'. Kata 'sanggup' memiliki maksud tentang kemampuan seseorang yang diungkapkan menggunakan modalitas dinamik kemampuan. Data M.Di 2 tersebut sesuai dengan pendapat Alwi (1992, hal. 261) yang menyatakan bahwa modalitas dinamik merupakan modalitas yang digunakan untuk mengungkapkan tentang kemampuan yang ditandai oleh penggunaan kata dapat, bisa, mampu, dan sanggup. Atas landasan teori tersebutlah, data M.Di 2 di atas digolongkan pada data tuturan modalitas dinamik yang memiliki maksud menjelaskan kemampuan seseorang.

Berdasarkan analisis data M.Di 2 di atas, data M.Di 2 dapat dikategorikan menjadi modalitas 
dinamik. Oleh karena itu, dapat disimpulkan bahwa: (1) data M.Di 2 dikategorikan sebagai modalitas dinamik karena terdapat kata 'sanggup'; (2) data M.Di 2 tidak bisa dikategorikan sebagai modalitas dinamik, apabila pada data M.Di 2 tidak terdapat kata 'sanggup' sehingga tidak ada kejelasan maksud pada data M.Di 2 tersebut; dan (3) data M.Di 2 mengandung unsur menyatakan kemampuan seseorang.

\section{SIMPULAN}

Berdasarkan hasil analisis data terhadap penggunaan modalitas bahasa Indonesia dalam Talk Show Mata Najwa, dapat disimpulkan bahwa tuturan modalitas bahasa Indonesia sering digunakan dalam ungkapan orasi. Penggunaan modalitas bahasa Indonesia yang ditemukan dalam Mata Najwa episode 10 Oktober 2018 yang berjudul "Satu atau Dua", yaitu 32 tuturan yang terdiri dari 12 tuturan modalitas intensional,13 tuturan modalitas epistemik, 5 tuturan modalitas deontik dan 2 tuturan modalitas dinamik. Adapun modalitas yang sering digunakan dalam orasi pada talk show Mata Najwa yaitu modalitas epistemik yang mengandung unsur keharusan. Modalitas epistemik sering digunakan dengan tujuan untuk meyakinkan mitra tutur terhadap orasi yang dilakukan. Kata yang sering digunakan dalam mengungkapkan modalitas epistemik yaitu kata 'harus' yang digunakan untuk mengajak mitra tutur dalam orasi yang dilakukan oleh penutur.

Modalitas bahasa Indonesia dapat digunakan dalam berbagai maksud tuturan dan memiliki dampak yang besar dalam tuturan itu sendiri. Dampak yang dimaksud yaitu pada penggunaan kata, frasa, dan kalimat yang mengandung modalitas. Apabila kata, frasa, dan kalimat tersebut tidak digunakan, maka dapat menimbulkan ketidakjelasan pada maksud tuturan. Bahkan bisa menimbulkan kesalahan persepsi tuturan terhadap mitra tutur. Selain itu, apabila kata, frasa, dan kalimat tersebut tidak digunakan, maka tuturan tersebut bisa beralih fungsi menjadi kalimat berita..

\section{DAFTAR RUJUKAN}

Alwi, Hasan. 1992. Modalitas dalam Bahasa Indonesia. Yogyakarta: Penerbit Kanisius.

Afyolanda, Imeylda, dkk. Jurnal Bahasa: Modalitas Kalimat pada Antologi Cerita Pendek Lukisan Kaligrafi Karya A. Mustofa Bisri. Jember: Universitas Jember.

Chaer, Abdul. 2012. Linguistik Umum. Jakarta: Rineka Cipta.
Damayanti, Tia. 2012. Adverbia Penanda Modalitas dalam Novel Karya Andrea Hirata: Suatu Kajian Stuktur dan Makna. Penerbit: Universitas Padjadjaran.

F, Yusef Ahmadi. Jurnal GRAMATIKA: Analisis Modalitas Tuturan Basuki Cahaya Purnama dalam Wacana Kalijodo. Bandung: STKIP Siliwangi.

Faradi, Abdul Azis. 2015. Jurnal Ilmu Bahasa: Kajian Modalitas Linguistik Fungsional Sistemik pada Teks Debat Capres-Cawapres pada PILPRES 2014-2019 dan Relevansinya dengan Pembelajaran Wacana di Sekolah.

Prihantoro, Edy \& Fitriani, Dinda Rakhma. 2015. Prosiding PESAT: Modalitas dalam Teks Berita Media Online. Depok: Universitas Gunadarma.

Santoso, Anang. 2008. Penggunaan Gramatika dalam Wacana Politik: Studi Representatif Bahasa Sebagai Sistem Makna Sosial dan Politik. Malang: Universitas Malang.

Saputri, Dini Nur'ainy Gita. PROSIDING SEMNAS: Kategori yang Dimodifikasi oleh Adverbia Penanda Modalitas dan Implementasi Pembelajarannya.Universitas Muhammadiyah Surakarta.

Wijana, I Dewa Putu. 2015. Pengantar Semantik Bahasa Indonesia. Yogyakarta: Pustaka Pelajar.. 
